\title{
Uji Diagnostik C-Reactive Protein pada Pneumonia Bakteri Komunitas Anak
}

\author{
Ikhsan Marzony, ${ }^{*}$ Finny Fitry Yani, ${ }^{*}$ Efrida** \\ *Departemen Ilmu Kesehatan Anak, ** Departemen Patologi Klinik Fakultas Kedokteran Universitas Andalas/RS Dr. M.Djamil, \\ Padang
}

Latar belakang. Polymerase chain reaction (PCR) merupakan teknik untuk menentukan agen penyebab pneumonia dengan sensitivitas dan spesifisitas yang tinggi, tetapi harganya mahal dan tidak tersedia di semua tempat. C-reactive protein (CRP) juga dapat digunakan untuk memprediksi infeksi bakteri dan memiliki keunggulan yang lain, yakni harganya yang murah dan hampir tersedia di semua laboratorium.

Tujuan. Mengetahui sensitivitas, spesifisitas, nilai prediksi positif, dan nilai prediksi negatif CRP pada pneumonia bakteri komunitas anak.

Metode. Penelitian cross sectional pada 62 subjek di Bagian Ilmu Kesehatan Anak RS. Dr. M. Djamil Padang dari Desember 2013 sampai Oktober 2014. Subjek dipilih dengan teknik konsekutif. Dilakukan uji CRP dan teknik PCR sebagai baku emas. Duapuluh tiga sampel diekslusi karena menderita penyakit jantung bawaan (7), sepsis (6), telah mendapatkan antibiotik (4), dan orang tua menolak pemeriksaan (6) sehingga total sampel menjadi 39 anak.

Hasil. Sebagian besar subjek penelitian adalah laki-laki (59\%) dan kelompok umur terbanyak 2-11 bulan (48,7\%). Sensitivitas CRP dengan cut off point $8 \mathrm{mg} / \mathrm{L}$ adalah $51,6 \%$, spesifisitas $75 \%$, nilai prediksi positif $88,8 \%$, nilai prediksi negatif $28,6 \%$. Pada cut off point $10 \mathrm{mg} / \mathrm{L}$, sensitivitas CRP adalah 41,9\%, spesifisitas 87,5\%, nilai prediksi positif $92,9 \%$, nilai prediksi negatif $28 \%$. Kesimpulan. C-reactive protein tidak dapat digunakan sebagai uji tapis terhadap pneumonia bakteri komunitas anak. Sari Pediatri 2015;17(5):391-5.

Kata kunci: pneumonia, $C$-reactive protein (CRP), teknik polymerase chain reaction (PCR)

\section{Diagnostic Test on C-Reactive Protein in Childhood Community Bacterial Pneumonia}

\author{
Ikhsan Marzony, Finny Fitry Yani, Efrida
}

Background. Polymerase Chain Reaction (PCR) technique which has high sensitivity and specificity. Unfortunately, this technique is expensive and not available in many regions. C-Reactive Protein (CRP) also can be used to predict bacterial infection. The advantages of CRP are cheaper and widely available

Objective. To know the sensitivity, specificity, positive predictive value and negative predictive value of CRP on childhood community acquired pneumonia.

Method. A cross sectional study was conducted on 62 patients at Pediatric Health Department of Dr. M. Djamil Hospital Padang from December 2013 to October 2014. The samples were selected consecutively, and then examined with CRP and PCR technique. Twenty three patients were excluded because of congenital heart disease (7), sepsis (6), prior antibiotics (4), and parental refusal (6). Finally there were only 39 samples studied

Results. Most of the samples were boys (59\%) and aged group in between 2-11 months old (48.7\%). CRP sensitivity with cut-off point $8 \mathrm{mg} / \mathrm{L}$, was $51.6 \%$, specificity $75 \%$, positive predictive value $88.8 \%$, negative predictive value $28.6 \%$, while with cut-off point $10 \mathrm{mg} / \mathrm{L}$ CRP sensitivity was $41.9 \%$, specificity $87.5 \%$, positive predictive value $92.9 \%$, negative predictive value $28 \%$ Conclusion. CRP is supposed to not be used as screening test for bacterial pneumonia. Sari Pediatri 2015;17(5):391-5.

Keywords: pneumonia, C-reactive protein (CRP), polymerase chain reaction (PCR) technique

\footnotetext{
Alamat korespondensi: Dr. Ikhsan Marzony, SpA. BIKA FK Universitas Andalas / RS Dr. M. Djamil Jl. Perintis Kemerdekaan Padang 25121 Indonesia. Telp.+62751 37913. E-mail: ihsanmarzony@yahoo.com
} 
Ikhsan Marzony dkk: Uji diagnostik CRP pada pneumonia bakteri komunitas anak

$\mathrm{P}$ neumonia adalah inflamasi parenkim paru yang dihubungkan dengan konsolidasi alveoli. ${ }^{1}$ Pneumonia komunitas atau community acquired pneumonia (CAP) merupakan salah satu penyebab kematian tersering pada anak di bawah usia lima tahun (balita). Di negara maju seperti Eropa dan Amerika Utara dilaporkan insiden pneumonia 34-40 kasus per 1000 anak. $^{2}$ Di negara berkembang, dalam 5 tahun pertama kehidupan, pada 1000 anak terdapat 100-150 kasus pneumonia berat dan 21\% menyebabkan kematian. ${ }^{3}$ Prevalensi pneumonia pada bayi dan balita di Sumatera Barat berturut-turut adalah $0,7 \%$ dan $0,8 \%{ }^{4}$

Penyebab pneumonia beragam, dua penyebab terbanyak adalah virus dan bakteri yang sulit dibedakan berdasarkan manifestasi klinis, radiologis, dan laboratorium rutin. ${ }^{5,6}$ Biakan bakteri memerlukan waktu beberapa hari serta tidak tersedia di semua tempat dan hasil positif hanya pada 30\%-50\% pasien, sedangkan biopsi jaringan paru sebagai baku emas bersifat invasif dan tidak diindikasikan. ${ }^{7,8}$ Kesulitan dalam mengetahui penyebab pasti pneumonia mengakibatkan pemberian antibiotik dilakukan secara empiris. Oleh karena itu, diperlukan parameter lain yang dapat segera menentukan diagnosis pneumonia bakteri sehingga pemberian antibiotik menjadi lebih tepat. ${ }^{9-11}$

C-Reactive Protein (CRP) adalah salah satu penanda yang dapat dipakai untuk memprediksi infeksi bakteri, ${ }^{12,13}$ merupakan suatu reaktan fase akut berukuran $23 \mathrm{kDa}$, dihasilkan oleh hati yang dikontrol oleh Interleukin-6 (IL-6), dan mempunyai waktu paruh yang panjang (18-20) jam. Individu tanpa inflamasi biasanya memiliki kadar CRP $<1$ $\mathrm{mg} / \mathrm{L}$, dan kadar CRP bisa meningkat sampai 100 kali lipat kadar normal pada kasus inflamasi akut seperti infeksi, trauma, dan pembedahan. ${ }^{6,14,15}$ Pemeriksaan ini lebih mudah, murah, dan banyak tersedia di berbagai laboratorium.

Saat ini, teknik polymerase chain reaction (PCR) berperan sebagai alat diagnostik pada infeksi saluran nafas. Metode ini lebih cepat dan lebih sensitif dibandingkan kultur, lebih spesifik mendeteksi mikroorganisme dalam jumlah yang sangat kecil sehingga dapat mendeteksi virus, seperti M. pneumoniae, C. pneumonia, Mycobacterium sp, Bordetella pertusis, dan bakteri lainnya. Saat ini, teknik PCR sudah digunakan sebagai baku emas dalam mendiagnosis pasien bakterimia dengan sensitivitas yang baik dan spesifisitas yang tinggi. ${ }^{16}$ Kelemahan pemeriksaan menggunakan teknik PCR ini adalah harganya yang mahal dan tidak tersedia di semua tempat.

\section{Metode}

Penelitian dengan desain cross sectional yang dilakukan di bagian Ilmu Kesehatan Anak dan laboratorium Patologi Klinik RS. Dr. M. Djamil Padang, serta laboratorium Biomedik Fakultas Kedokteran Universitas Andalas, dari bulan Desember 2013-Oktober 2014. Kriteria iklusi adalah pasien pneumonia komunitas usia 2 bulan-14 tahun dan menyetujui ikut penelitian. Kriteria eksklusi adalah pasien pneumonia nosokomial atau telah mendapat antibiotik sebelumnya atau menderita penyakit penyerta lainnya, yaitu penyakit jantung bawaan, demam rematik, pertusis, gizi buruk, sepsis, penyakit dengan defisiensi imunologis, trauma (pembedahan, luka bakar, fraktur), reaksi alergi dan penyakit autoimun, asma, pankreatitis akut, penyakit kronik dan terminal (hati dan ginjal), penyakit keganasan, syok kardiogenik, infeksi jamur, malaria, tuberkulosis, meningitis, poliomyelitis.

Penelitian dilakukan setelah lulus kaji etik dari Komisi Etik Penelitian Fakultas Kedokteran Universitas Andalas nomor 346/KEP/FK/2014 dan mendapat persetujuan dari orangtua pasien. Pada semua sampel penelitian diambil darah $2 \mathrm{cc}$ di daerah vena cubiti secara aseptik dan antiseptik, kemudian disentrifus $3000 \mathrm{rpm}$ selama 2 menit, dan digunakan untuk pemeriksaan CRP dengan metode ELISA dan pemeriksaan bakteri dengan teknik PCR. Sebelum digunakan, darah disimpan pada suhu $-20^{\circ} \mathrm{C}$ sehingga stabil selama 3 bulan.

\section{Hasil}

Selama periode penelitian didapatkan 62 orang anak dirawat inap dengan diagnosis pneumonia. Duapuluh tiga orang anak dieksklusi karena menderita penyakit jantung bawaaan (7), sepsis (6), telah mendapatkan antibiotik sebelumnya (6), dan orang tua menolak pengambilan darah (4) sehingga terdapat 39 orang anak yang dianalisis lebih lanjut. Karakteristik sampel penelitian tertera pada Tabel 1 .

Kadar CRP sebagai prediksi infeksi bakteri berdasarkan penelitian sebelumnya dapat dinilai pada cut off point $8 \mathrm{mg} / \mathrm{L}$ dan $10 \mathrm{mg} / \mathrm{L}$. Sensitivitas, 
spesifisitas, dan nilai prediksi ditampilkan dalam bentuk tabel $2 \times 2$, untuk menilai kemampuan CRP membedakan infeksi bakteri atau non bakteri pada pasien pneumonia anak, dibandingkan dengan teknik PCR sebagai baku emas. Hasil pemeriksaan uji diagnostik tersebut tertera pada Tabel 2 dan 3 .

Sensitivitas 51,6\%, spesifisitas 75\%, nilai prediksi positif $88,8 \%$, nilai prediksi negatif $28,6 \%$.

Sensitivitas $41,9 \%$, spesifisitas $87,5 \%$, nilai prediksi positif $92,9 \%$, nilai prediksi negatif $28 \%$.

Tabel .1 Karakteristik subjek penelitian

\begin{tabular}{lc}
\hline Karakteristik & $\begin{array}{c}\text { Jumlah } \\
(\mathrm{n}=39)\end{array}$ \\
\hline $\begin{array}{l}\text { Jenis kelamin }(\mathrm{n}, \%) \\
\text { Laki-laki }\end{array}$ & $23(59)$ \\
Perempuan & $16(41)$ \\
Kelompok umur (n,\%) & \\
2-11 bulan & $19(48,7)$ \\
1-4 tahun & $18(46,2)$ \\
$5-12$ tahun & $(5,1)$ \\
\hline
\end{tabular}

Tabel 2. Hasil uji CRP dengan cut off point $8 \mathrm{mg} / \mathrm{L}$ dibandingkan dengan teknik PCR

\begin{tabular}{|c|c|c|c|}
\hline \multirow{2}{*}{ Kadar CRP (mg/L) } & \multicolumn{2}{|c|}{ PCR } & \multirow{2}{*}{ Jumlah } \\
\hline & Positif & Negatif & \\
\hline CRP $\geq 8$ & 16 & 2 & 18 \\
\hline $\mathrm{CRP}<8$ & 15 & 6 & 21 \\
\hline Jumlah & 31 & 8 & 39 \\
\hline
\end{tabular}

Tabel 3. Hasil uji CRP dengan cut off point $10 \mathrm{mg} / \mathrm{L}$ dibandingkan dengan teknik PCR

\begin{tabular}{lccc}
\hline \multirow{2}{*}{ Kadar CRP } & \multicolumn{2}{c}{ PCR } & \multirow{2}{*}{ Jumlah } \\
\cline { 2 - 3 } & Positif & Negatif & \\
\hline $\mathrm{CRP} \geq 10 \mathrm{mg} / \mathrm{L}$ & 13 & 1 & 14 \\
$\mathrm{CRP}<10 \mathrm{mg} / \mathrm{L}$ & 18 & 7 & 25 \\
\hline Jumlah & 31 & 8 & 39 \\
\hline
\end{tabular}

\section{Pembahasan}

Karakteristik dasar penelitian kami mendapatkan jenis kelamin terbanyak adalah laki-laki (59\%). Hasil tersebut hampir sama dengan laporan penelitian Kisworini $\mathrm{dkk}^{17}$ dan Beyeng $\mathrm{dkk}^{18}$ yang mendapatkan penderita laki-laki lebih banyak dibandingkan perempuan (55\% dan 59,4\%). Penelitian Koster $\mathrm{dkk}^{19}$ dan Subanada $\mathrm{dkk}^{10}$ juga melaporkan bahwa penderita laki-laki lebih banyak (54\% dan 60\%). Namun, hasil tersebut sedikit berbeda dengan penelitian yang dilakukan oleh Irawati $\mathrm{dkk}^{9}$ yang melaporkan bahwa penderita perempuan lebih banyak (55,2\%).

Pada penelitian kami, kelompok umur terbanyak yang menderita pneumonia adalah kelompok umur 2-11 bulan $(48,7 \%)$. Hasil tersebut sama dengan penelitian Irawati $\mathrm{dkk}^{9}$ yang melaporkan bahwa penderita pneumonia terbanyak pada kelompok umur 2-11 bulan (72,4\%). Penelitian Padrisa $\mathrm{dkk}^{20}$ melaporkan umur rata-rata penderita pneumonia terbanyak adalah umur 1-4 tahun (49\%). Insiden puncak pneumonia adalah umur 1-5 tahun dan menurun dengan bertambahnya usia. ${ }^{21}$

Sintesis protein fase akut, termasuk CRP, oleh hepatosit dimodulasi oleh sitokin. Stimulus fase akut, seperti infeksi atau trauma fisik, akan menginduksi kerusakan jaringan dan mengaktifkan makrofag. Makrofag yang teraktivasi akan melepaskan sitokin ke dalam aliran darah. Interleukin-1 $\beta, I L-6$, dan tumor necrosis factor $\alpha(T N F \alpha)$ merupakan regulator terpenting dalam sintesis CRP. Adanya gangguan dalam proses ini dapat menyebabkan sintesis yang abnormal. ${ }^{22}$

Beberapa penelitian dikutip oleh Vasquez $\mathrm{dkk}^{22}$ yang menunjukkan CRP sebagai marker respons inflamasi yang baik dalam memprediksi pneumonia karena virus atau bakteri. Vasquez mengutip laporan penelitian Adnet dkk yang mendapatkan bahwa kadar CRP tinggi membantu dalam diagnosis pneumonia bakteri, sekunder terhadap aspirasi. Disamping itu, Vaquez juga mengutip laporan penelitian Ponka dkk yang mendapatkan bahwa pneumonia yang disebabkan oleh S. pneumonia, khususnya saat bakterimia, berhubungan dengan respons tubuh yang lebih besar (kadar IL-6 dan CRP yang lebih tinggi) dibandingkan penyebab yang lain (M. pneumonia dan virus). Namun Kono $\mathrm{dkk}^{23}$ melaporkan hasil yang berbeda, pemeriksaan kadar CRP bukanlah metode yang adekuat untuk membedakan infeksi bakteri atau non bakteri, walaupun kadar yang rendah tidak menyingkirkan kemungkinan infeksi bakteri pada anak.

Teknik PCR merupakan baku emas yang digunakan untuk memprediksi infeksi bakteri pada penelitian kami. Umumnya, penyebab pneumonia berat disebabkan oleh bakteri, tetapi agen penyebab kadang sukar diidentifikasi. Pada $>50 \%-70 \%$ kasus, 
Ikhsan Marzony dkk: Uji diagnostik CRP pada pneumonia bakteri komunitas anak

S. pneumoniae merupakan patogen yang paling sering ditemukan. ${ }^{3,22}$

Kami mendapatkan spesifisitas CRP dengan cut off point $10 \mathrm{mg} / \mathrm{L} 87,5 \%$, artinya uji ini dapat memprediksi infeksi bakteri dengan angka yang cukup tinggi jika hasil uji positif, yakni hanya 12,5\% anak dengan kadar CRP $>10 \mathrm{mg} / \mathrm{L}$ yang infeksinya bukan disebabkan oleh bakteri, tetapi sensitivitas uji ini rendah sehingga infeksi bakteri tidak dapat disingkirkan jika hasil uji negatif. Sensitivitas uji CRP, dengan cut off point $8 \mathrm{mg} / \mathrm{L}$ dan $10 \mathrm{mg} / \mathrm{L}$ hanya $51,6 \%$ dan 41,9\%, menggambarkan kemampuan CRP yang rendah sebagai uji tapis. Koster $\mathrm{dkk}^{19}$ dengan cut off point $10 \mathrm{mg} / \mathrm{L}$ mendapatkan hasil yang lebih tinggi, yaitu sensitivitas $90 \%$, spesifisitias $40 \%$, nilai prediksi positif $62 \%$, dan nilai prediksi negatif $79 \%$.

Beberapa penyebab hasil negatif semu pada uji CRP telah dilaporkan. Kadar CRP serum akan meningkat dalam 4 sampai 6 jam setelah stimulus inflamasi atau kerusakan jaringan akut, bertambah 2 kali lipat setiap 8 jam dan mencapai puncak dalam 36-50 jam. Konsekuensinya, sintesis CRP mungkin belum cukup dalam 12 jam setelah stimulus fase akut, mungkin hal inilah yang dapat menjelaskan hasil negatif semu pada banyak kasus, tetapi kapan awal proses inflamasi terjadi sulit ditentukan pada penelitian ini. Penyebab hasil negatif semu uji CRP pada penelitian kami masih belum jelas. Alasan lain yang mungkin adalah beberapa sitokin memengaruhi sintesis CRP, tetapi hipotesis ini tidak dapat diuji karena analisis sitokin tidak dikerjakan. Penelitian sitokin lebih lanjut, seperti IL-6 dan terutama pada stadium awal infeksi bakterial, diperlukan untuk mendapatkan kesimpulan yang lebih definitif. ${ }^{23,24}$

Penelitian yang dilakukan oleh Vasquez $\mathrm{dkk}^{22}$ melaporkan bahwa kadar CRP pada pasien pneumonia komunitas yang disebabkan oleh L. pneumophila lebih tinggi daripada patogen penyebab yang lain sehingga menimbulkan pertanyaan apakah $L$. pneumophila mencetuskan jalur inflamasi yang lebih atau berbeda dibandingkan mikroorganisme lain? Pola produksi sitokin dan protein fase akut tidak sama pada kondisi inflamasi yang berbeda. Semakin besar terjadi kerusakan paru, semakin tinggi pula kadar CRP. Peran respons inflamasi pada infeksi yang disebabkan oleh L. pneumophila dibandingkan pneumonia yang disebabkan oleh agen atipikal lainnya perlu penelusuran lebih lanjut. Penelitian ini tidak mengindentifikasi agen penyebab dari pneumonia komunitas sehingga tidak dapat memperkirakan respons inflamasi secara spesifik yang ditimbulkan oleh masing-masing mikroorganisme.

Kami mendapatkan hasil uji CRP yang positif pada uji PCR yang negatif (positif semu), yaitu 2 kasus pada cut off point CRP $8 \mathrm{mg} / \mathrm{L}$ dan 1 kasus pada cut off point CRP $10 \mathrm{mg} / \mathrm{L}$. Hal tersebut disebabkan karena perbedaan kadar konsentrasi CRP yang digunakan sebagai batas screening untuk memprediksi pneumonia bakterial. Seperti laporan penelitian Virkki $\mathrm{dkk}^{25}$ yang menggunakan kadar CRP $>80 \mathrm{mg} / \mathrm{L}$ sebagai batasan infeksi bakteri (sensitivitas 52\%, spesifisitas $72 \%)$. Pemakaian batas kadar CRP $>40 \mathrm{mg} / \mathrm{L}$ didapatkan banyak hasil positif semu, demikian juga jika menggunakan batasan kadar CRP $>120 \mathrm{mg} / \mathrm{L}$ didapatkan banyak hasil negatif semu. Penelitian yang dilakukan oleh Moulin ${ }^{12}$ mendapatkan cut off point 20 $\mathrm{mg} / \mathrm{L}$ untuk memprediksi bakteri, dengan sensitivitas $88,4 \%$ dan spesifisitas $40 \%$, kadar prediksi positif $71,6 \%$, dan kadar prediksi negatif 66,6\%. Koster ${ }^{19}$ melaporkan bahwa dengan kadar cut off point 20 $\mathrm{mg} / \mathrm{L}$ didapatkan sensitivitas $81 \%$, spesifisitas $53 \%$, nilai prediksi positif $65 \%$, dan nilai prediksi negatif $72 \%$. Akter $\mathrm{dkk}^{27}$ melaporkan bahwa sensitivitas PCR 99,5\%, spesifisitas 88,2\% dalam menegakkan etiologi pneumonia komunitas, artinya masih ada kemungkinan hasil positif 0,5\% jika hasil uji negatif.

Disimpulkan pada penelitian ini bahwa uji CRP tidak dapat digunakan sebagai uji tapis terhadap pneumonia bakteri komunitas anak.

\section{Daftar pustaka}

1. Sectish TC, Prober CG. Pneumonia. Dalam: Kliegman RM BR, Jenson HB, Stanton BF, penyunting. Nelson Textbook of Pediatrics. Edisi ke-18. Philadepia: WB Saunders Company; 2007.h.1795-9.

2. Scott JA, Brooks WA, Peiris M, Holtzman D, Mulholland EK. Pneumonia research to reduce childhood mortality in the developing world. J Clin Invest 2008;18:1291-300.

3. Ostapchuk M, Roberts DM, Haddy R. Communityacquired pneumonia in infants and children. Am Fam Physician 2004;70:899-908.

4. Weber M, Hand F. Situasi pneumonia balita di Indonesia. Buletin Jendela Epidemiologi Pneumonia Balita 2010;3:110.

5. Stein RT, Marostica PJC. Community-acquired bakterial pneumonia. Dalam: Chernick V, Boat TF, Wilmott 
RW, Bush A, penyunting. Kendig's Disorder of the Respiratory Tract in Children. Edisi ke-7. Philadelphia: Saunders; 2006.h.441-52.

6. Rudan I, Boschi-Pinto C, Biloglav Z, Mulholland K, Campbell H. Epidemiology and etiology of Childhood pneumonia. Bull of the World Health Organization 2008;86:408-16.

7. Virkki R, Juven T, Rikalainen H, Svedstrom E, Mertsola J, Ruuskanen O. Differentiation of bacterial and viral pneumonia in children. Thorax 2002;57:438-41.

8. Kabra SK, Broor S, Lodha R, dkk. Can we identify acute severe viral lower respiratory tract infection clinically? Indian Pediatrics 2004;41:245-9.

9. Irawati HM, Ponpon S, Idjradinata. Kesesuaian kadar C reaktif protein dan procalcitonin dalam diagnosis pneumonia berat pada anak. Sari Pediatri 2010;12:4-7.

10. Subanada ID, Purniti NPS. Faktor-faktor yang berhubungan dengan pneumonia bakteri pada anak. Sari Pediatri 2010;12:3-5.

11. O'Connor E, Venkatesh B, Lipman J. Procalcitonin in critical illness. Critical Care and Res 2001;3:236-43.

12. Moulin F, Raymond J, Lorrot M, dkk. Procalcitonin in children admitted to hospital with community acquired pneumonia. Arch Dis Child 2001;84:332-6.

13. Simon L, Gauvin F, Amre DK, Louis PS, Lacroix J. Serum procalcitonin and C-reactive protein levels as markers of bacterial infection: a systematic review and meta-analysis. CID 2004;39:206-17.

14. Ridker P, Hennekens CH, Buring JE, Rifai N. C-reactive protein and other markers of inflammation in the prediction of cardiovascular disease in women. N Engl J Med 2000;342:836-43.

15. Juven T, Mertsola J, Waris M, Leinonen M, Ruuskanen O. Clinical responses to antibiotic therapy for communityacquired pneumonia. Eur J Pediatr 2004;163:140-4.

16. Stein RT, Marostica PJ. Community acquired backterial pneumonias. Dalam: Chernick V, Boat FT, penyunting.
Kendig's Disorders of the respiratory tract in children. Philadelpia: WB Saunders; 2006.h.453-61.

17. Kisworini P, Setyati A, Sutaryo. Mortality predictors of pneumonia in children. Paediatr Indones 2010;3:14953.

18. Beyeng RTD, Purniti PS, Naning R. Validity of bacterial pneumonia score for predicting bacteremia in children with pneumonia. Paediatr Indones 2011;51:322-6.

19. Koster MJ, Broekhuizen BD. Diagnostic properties of C-reactive protein for detecting pneumonia in children. Respiratory Medicine 2013;107:1087-93.

20. Padrisa D, Bassat Q, Morais L, dkk. Procacitonin and C-reactive protein as predictors of blood culture positivity among hospitalized children with severe pneumonia in Mozambique.Tropical Medicine and International Health 2012;17:1100-7.

21. Asih R, Landia S, Makmuri MS. Pneumonia. Continuing education IKA XXXVI. Surabaya. 2006.h.1-15.

22. Vasquez EG, Martinez JA, Mensa J, dkk. C-reactive protein level in community-aquired pneumonia. Eur Respir J 2003; 21:702-5.

23. Kono T, Otzuka M, Ito M, dkk. Negative C-reactive protein in children with bacterial infection. Pediatrics International 1999;41:496-9.

24. Smith RP, Lipworth BJ. C-reactive protein in simple community-acquired pneumonia. CHEST 1995;107: 1028-31.

25. Virkki R, Juven T, Rikailanen. Differentiation of bacterial and viral pneumonia in children. Thorax 2002;57:43841.

26. Setyoningrum RA, Landia S, Makmuri MS. Pneumonia. Naskah lengkap Continuing Education Ilmu Kesehatan Anak XXXVI. 2006.h.1-25.

27. Akter S, Shamsuzzaman SM, Jahan F. Community acquired bacterial pneumonia: aetiology, laboratory detection and antibiotic susceptibility pattern. Malaysian J Pathol 2014;36:97-103. 